\title{
Anopheles (Kerteszia) cruzii (DIPTERA: CULICIDAE) IN PERIDOMICILIARY AREA DURING ASYMPTOMATIC MALARIA TRANSMISSION INTHE ATLANTIC FOREST: MOLECULAR IDENTIFICATION OF BLOOD-MEAL SOURCES INDICATES HUMANS AS PRIMARY INTERMEDIATE HOSTS
}

Karin KIRCHGATTER(1), Rosa Maria TUBAKI(2), Rosely dos Santos MALAFRONTE(3,4), Isabel Cristina ALVES(5), Giselle Fernandes Maciel de Castro LIMA(1), Lilian de Oliveira GUIMARÃES(1), Robson de Almeida ZAMPAULO(2) \& Gerhard WUNDERLICH(6)

\begin{abstract}
SUMMARY
Anopheles (Kerteszia) cruzii has been implicated as the primary vector of human and simian malarias out of the Brazilian Amazon and specifically in the Atlantic Forest regions. The presence of asymptomatic human cases, parasite-positive wild monkeys and the similarity between the parasites infecting them support the discussion whether these infections can be considered as a zoonosis. Although many aspects of the biology of An. cruzii have already been addressed, studies conducted during outbreaks of malaria transmission, aiming at the analysis of blood feeding and infectivity, are missing in the Atlantic Forest. This study was conducted in the location of Palestina, Juquitiba, where annually the majority of autochthonous human cases are notified in the Atlantic Forest of the state of São Paulo. Peridomiciliary sites were selected for collection of mosquitoes in a perimeter of up to $100 \mathrm{~m}$ around the residences of human malaria cases. The mosquitoes were analyzed with the purpose of molecular identification of blood-meal sources and to examine the prevalence of Plasmodium. A total of 13,441 females of An. (Ker.) cruzii were collected. The minimum infection rate was calculated at $0.03 \%$ and $0.01 \%$, respectively, for $P$. vivax and P. malariae and only human blood was detected in the bloodfed mosquitoes analyzed. This data reinforce the hypothesis that asymptomatic human carriers are the main source of anopheline infection in the peridomiciliary area, making the probability of zoonotic transmission less likely to happen.
\end{abstract}

KEYWORDS: Asymptomatic malaria; Atlantic forest; Anopheles (Kerteszia) cruzii; Plasmodium malariae; Plasmodium vivax.

\section{INTRODUCTION}

Currently, the Amazon Region concentrates $99.8 \%$ of the malaria cases described in Brazil, with approximately 306,000 cases registered in $2009^{28}$. Malaria outside the Amazon region is situated mainly in Atlantic forest regions, due to the presence of bromeliads where Anopheles mosquitoes of the subgenus Kerteszia use the axils as larval habitat ${ }^{28}$. An. (Ker.) cruzii and An. (Ker.) bellator are considered malaria vectors, and the first is the primary vector of human and simian malaria in these regions ${ }^{6,7,10,12}$. Accordingly, since the 1960's there is a discussion whether these infections, termed "forest-malaria" or "bromeliad-malaria", can be considered as a zoonosis, where monkeys possibly act as reservoirs ${ }^{8}$.

Some data support the hypothesis that malaria can be a zoonosis in the Atlantic Forest. In relation to the vector, synanthropy of $A n$. cruzii has been demonstrated in Atlantic Forest areas of the state of São Paulo ${ }^{16,20}$. These studies have shown that females may fly to the anthropic environment to feed on blood mainly in the domestic and peridomestic areas and then return to the natural environment ${ }^{20}$. Moreover, a high vertical mobility, with distribution from ground level to tree tops, has been shown in $A n$. cruzili $^{36}$. In relation to the hosts, simian malaria was shown to frequently occur in the forested coastal mountains of the Southeastern region, where $35 \%$ of the examined monkeys were positive for $P$. brasilianum or $P$. simian and the identification of natural accidental human infection due to $P$. simium ${ }^{9}$. The parasitological prevalence of $P$. vivax and $P$. malariae in wild monkeys from the Atlantic Forest has also been described in more recent studies ${ }^{11,39}$. Finally, the simian malaria parasites $P$. brasilianum and $P$. simium are genetically indistinguishable from those responsible for human malaria in the Atlantic forest, $P$. malariae and P. vivax, respectively ${ }^{13,25}$.

On the other hand, it is also important to note that human cases detected in the Atlantic forest are generally asymptomatic, showing only subpatent levels of parasites. These individuals figure as appropriate reservoir hosts because they are not routinely identified as parasite carriers by typical malaria control programs which monitor only patent malaria cases.

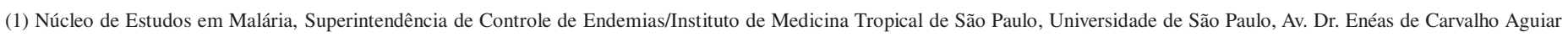
470, 05403-000 São Paulo, SP, Brazil.

(2) Laboratório de Entomologia Médica, Superintendência de Controle de Endemias, São Paulo, SP, Brazil.

(3) Laboratório de Protozoologia, Instituto de Medicina Tropical de São Paulo, Universidade de São Paulo, São Paulo, SP, Brazil.

(4) Departamento de Doenças Parasitárias e Infecciosas, Faculdade de Medicina, Universidade de São Paulo, São Paulo, SP, Brazil.

(5) Laboratórios de Investigação Médica, LIM49, Hospital das Clínicas, São Paulo, SP, Brazil.

(6) Departamento de Parasitologia, Instituto de Ciências Biomédicas II, Universidade de São Paulo, São Paulo, SP, Brazil.

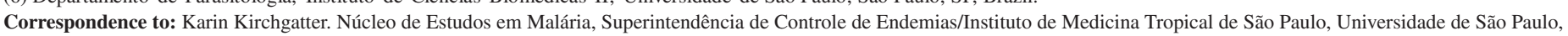
Av. Dr. Enéas de Carvalho Aguiar 470, 05403-000 São Paulo, SP, Brasil. E-mail: karink@usp.br 


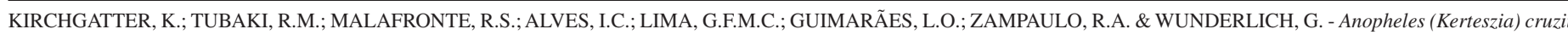
(Diptera: Culicidae) in peridomiciliary area during asymptomatic malaria transmission in the Atlantic Forest: molecular identification of blood-meal sources indicates humans as primary intermediate hosts. Rev. Inst. Med. Trop. Sao Paulo, 56(5): 403-9, 2014.

Despite the fact that many aspects of the biology of An. cruzii have been elucidated ${ }^{26}$, studies conducted in settings of asymptomatic malaria transmission, aiming at the analysis of vector blood feeding and infectivity, are missing for the Atlantic Forest. Using this approach, this study tried to screen individual mosquitoes for the presence of non-human blood, mainly monkey blood, in order to support or reject the hypothesis of zoonotic transmission of malaria in this region. The city of Juquitiba was chosen to investigate these aspects, as thirteen cases, almost one third of all autochthonous cases in the Atlantic Forest of the state of São Paulo, were notified there in $2007^{5}$. The location of Palestina was specifically chosen for being responsible for the identification of the largest number of cases in the region and because dwellings are in the vicinity of woods, where monkeys are frequently seen. The mosquitoes were analyzed with the purposes of (i) molecular identification of blood-meal sources; (ii) to examine the prevalence of Plasmodium; (iii) to collect information on seasonality; and (iv) to evaluate methods of Kerteszia sampling, with the final aim of contributing to the design of new strategies for asymptomatic malaria prevention and control in Atlantic Forest.

\section{MATERIAL AND METHODS}

Study Area: The city of Juquitiba is located in the metropolitan area of São Paulo, state of São Paulo, Brazil, and covers an area of $521.6 \mathrm{~km}^{2}$, with a population of 28,961 inhabitants, of whom $22.6 \%$ live in the rural area ${ }^{32}$. Juquitiba has an ecotourism economic activity that comprises activities such as canoeing, camping and fishing, due to the mountainous landscape and rivers. Concerning exposure to malaria vectors in peridomiciliary habitats, the local population consists mainly of employees who look after the properties and live near the cottages, as well as people who come from the city of São Paulo to spend the weekend at holiday cottages for recreation. The climate in this region is humid and subtropical ${ }^{24}$, with the coldest mean temperature below $18{ }^{\circ} \mathrm{C}$ in a dry winter (June-August) and the warmest month above $22^{\circ} \mathrm{C}$ in the wet summer season (December-February). The annual rainfall is about $1300 \mathrm{~mm}$ and the average altitude is $685 \mathrm{~m}$. In 2006 and 2007, 16 and 13 mainly asymptomatic malaria cases were reported in Juquitiba, respectively 5 .

Mosquito sampling and handling: Adult female mosquitoes were collected from January 2006 to September 2007 in the wet and dry seasons at eight sites in the peridomiciliary environment (Fig. 1). The collection sites have the same landscape features; they are rural human settlements with anthropic modifications and variable distances from patches of forest, allowing frequent contact of man-forest and manmosquitoes. The dwellings are scattered along Palestina Road, usually located near the forest, and the anthropic environment is constituted by extensive agricultural activities. The collection sites are connected by Embratel Road, Palestina Road and Olaria Road (Fig. 1B).

Mosquitoes were collected from January 2006 to September 2007 by: (i) Nasci aspirator ${ }^{27}$; (ii) Shannon trap ${ }^{34}$; and (iii) UV-CDC (Centers for Disease Control) light traps baited with $\mathrm{CO}_{2}{ }^{35}$. These methods were used from nine to $12 \mathrm{am}$, seven to nine $\mathrm{pm}$ and six pm to seven am, respectively, during wet (January to March) and dry (July to September) seasons, for three consecutive days per month, totaling 36 days.

Collections with Nasci aspirator were made to supply representative samples of blood-engorged resting females ${ }^{33}$. The Nasci aspirators were used in the early morning, in the proximity of bromeliads (Kerteszia breeding sites), to collect resting females at four peridomiciliary sites where malaria cases were identified. One collector went towards the canopy trees to aspirate near the bromeliads, for intervals of 15 minutes, to complete the three-hour period.

Collections with CDC light traps and Shannon traps were used to sample Plasmodium infected females. Ten CDC light traps with UV light baited with $\mathrm{CO}_{2}$ were distributed on site 4 , specifically in the peridomiciliary outskirts of the cottage. This site was chosen

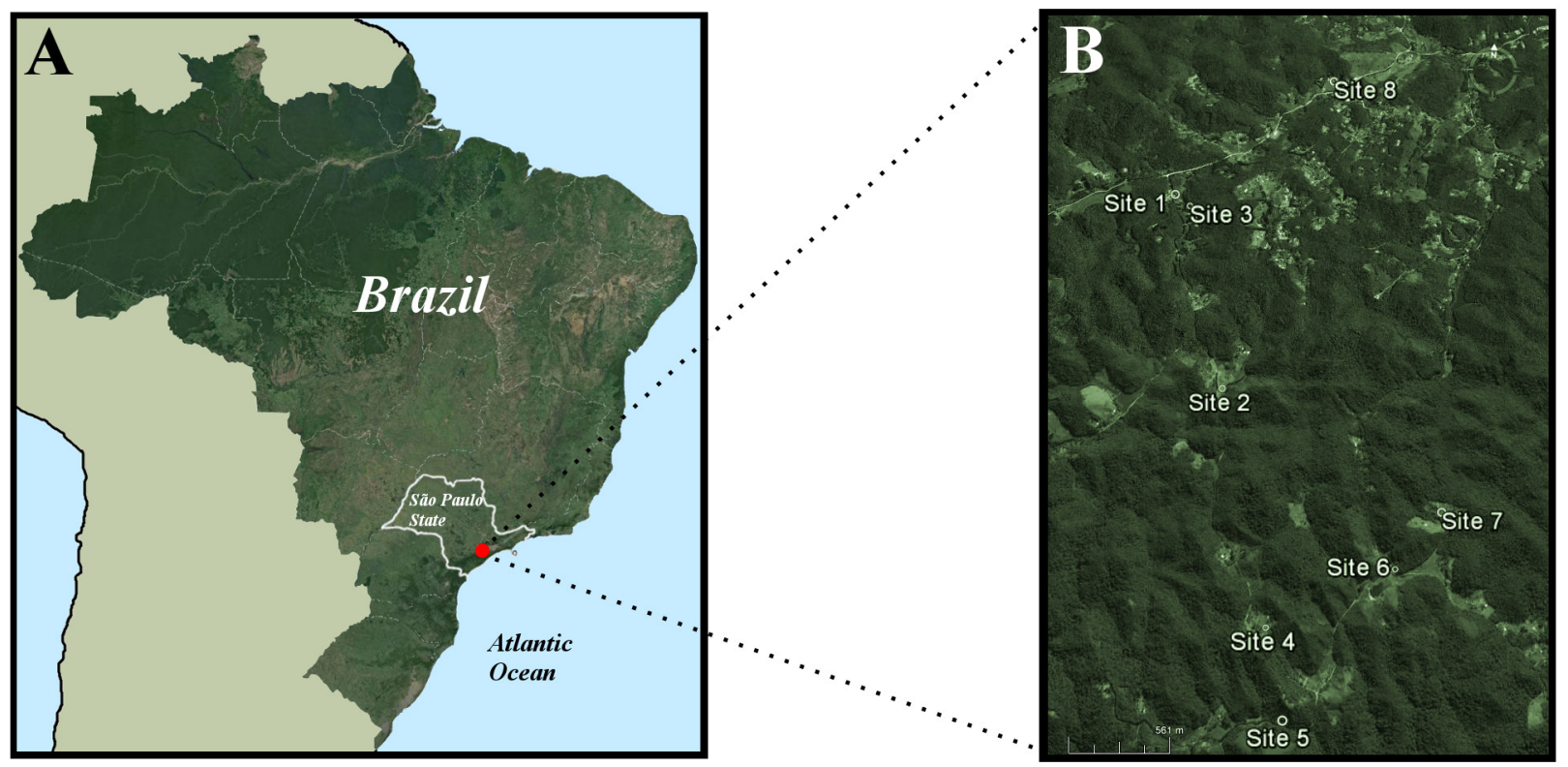

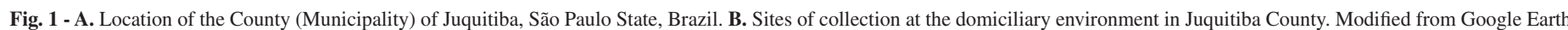
and Wikimedia Commons. 


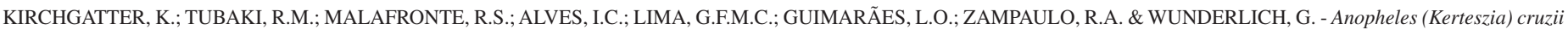

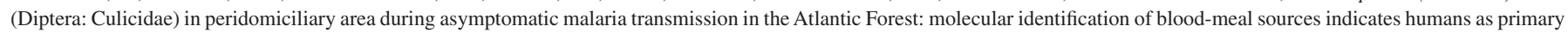
intermediate hosts. Rev. Inst. Med. Trop. Sao Paulo, 56(5): 403-9, 2014.

because the first malaria case detected in the parasitological survey done in January 2005 lives in this cottage. The complete data of the parasitological survey will be published elsewhere. Site 4 is a remnant of the forest in a steep relief with higher altitudes situated $40 \mathrm{~m}$ away from the cottage. The peridomiciliary area corresponds to open man-made fields with isolated trees without bromeliads. Samples were collected at site 4 to verify the abundance of Kerteszia subgenus in a high forest cover in a steeper area in the proximity of the dwelling. The traps were distributed in an altitudinal range of 711-778 $\mathrm{m}$ (above sea level) with $10 \mathrm{~m}$ of distance between each other. Altitudinal positions of mosquito traps were measured using portable GPS. The seasonal abundance of An. cruzii with the overall collections at site 4 (Fig. 1B) was estimated by using the William's mean ${ }^{21}$, and the altitudinal distribution of $A n$. cruzii abundances was compared in dry and wet seasons by the nonparametric Friedman test.

A comparison of the effectiveness of CDC light traps and the Shannon traps at sampling An. cruzii was carried out in the peridomiciliary habitats of the sites 1,2 and 6, where collections were conducted simultaneously. The collections were compared by standardizing their number to obtain the monthly Williams geometric mean. The comparison of the anopheline abundances was verified by Wilcoxon's matched-pairs test.

Adult mosquitoes were killed with chloroform steam and transported to the laboratory, where their specimens were identified on chilled tables with a stereomicroscope and using identification keys ${ }^{18,40}$. All mosquitoes with fresh or visible blood remnants were individually placed in $1.5-\mathrm{mL}$ microcentrifuge tubes, sealed with parafilm, labeled according to species, collection site and stored at $-20^{\circ} \mathrm{C}$.

Mosquito gDNA extraction and PCR amplification of Plasmodium SSU fragment: DNA from each mosquito was extracted as described ${ }^{31}$, and the assay to detect Plasmodium infection was performed in pools of ten mosquitoes. The pools were separated by species, day of capture and type of trap. PCR amplification was carried out according to a full-nested protocol $^{38}$, which uses oligonucleotides in conserved sequences, in the small subunit (SSU) ribosomal RNA of human Plasmodium species in a first reaction. The second amplification was carried out with specific primers for three human Plasmodium species circulating in Brazil ( $P$. falciparum, $P$. vivax and $P$. malariae). PCR products were electrophoresed in $2 \%$ agarose gels, stained with ethidium bromide and visualized under UV-light. The minimum infection rate (MIR) was calculated as the ratio of the number of positive pools to the total number of mosquitoes tested ${ }^{37}$.

gDNA extraction from blood-fed mosquitoes and blood meal identification: Genomic DNA of blood fed mosquitoes was obtained using PureLink ${ }^{\mathrm{TM}}$ Genomic DNA Purification Kit (Invitrogen). PCR was used to amplify host DNA from the mosquito blood meal using primers $\mathrm{L} 14841$ and $\mathrm{H} 15149^{23}$ or B1 and $\mathrm{B} 6^{30}$ designed to amplify, respectively, fragments with $\sim 300 \mathrm{bp}$ and $\sim 1 \mathrm{~kb}$ of the mitochondrial $c y t b$ gene from a wide array of animals, including mammals, birds, amphibians, reptiles and fishes. This methodology was successfully used to identify the blood meal sources in mosquitoes from São Paulo $\mathrm{Zoo}^{2}$.

Amplified fragments were purified from gels and sequenced directly using the corresponding flanking primers. Sequences were identified by comparison to the GenBank DNA sequence database (www.ncbi.nlm.nih. gov/blast/Blast.cgi). Positive identification and host species assignment were made when exact or nearly exact matches (> 98\%) were obtained. Human cytb fragments show less than $86 \%$ of sequence identity with those from different primate species normally described in the Atlantic Forest of the state of São Paulo (Callithrix jacchus, Alouatta guariba and Cebus apella) (data not shown).

\section{RESULTS}

Anopheline abundance, distribution and seasonal variation: A total of 13,462 Anopheles females were collected, including 13,441 of An. (Ker.) cruzii, 13 of An. (Nys.) evansae, six of An. (Nys.) lutzii, one of An.(Nys.) galvaoi and one of An. (Ker.) bellator. Since the study of An. (Ker.) cruzii is the objective of this work, and this species corresponded to $99.8 \%$ of the collected individuals, only these mosquitoes were used for infection rate determination and blood meal identification. From the 13,441 of An. (Ker.) cruzii collected, $55.2 \%$ were obtained in CDC, $42 \%$ in Shannon traps and $2.8 \%$ in Nasci aspirators (Table 1).

Table 1

Females of An. (Ker.) cruzii collected by different methods, at eight peridomiciliary collection sites, in Juquitiba, State of São Paulo, from January 2006 through September 2007

\begin{tabular}{|c|c|c|c|c|}
\hline Site & $\begin{array}{c}\text { Position } \\
\text { according GPS\# }\end{array}$ & $\begin{array}{c}\text { Malaria } \\
\text { case* }^{*}\end{array}$ & Method & $\begin{array}{c}\text { Mosquitoes } \\
\text { collected }\end{array}$ \\
\hline \multirow{2}{*}{1} & $24^{\circ} 00^{\prime} 01.2 ” \mathrm{~S}$ & \multirow{2}{*}{$19 / 05 / 2005$} & $\mathrm{CDC}$ & 1 \\
\hline & $47^{\circ} 06^{\prime} 12.9^{\prime \prime} \mathrm{W}$ & & Shannon & 51 \\
\hline \multirow{3}{*}{2} & \multirow{3}{*}{$\begin{array}{l}24^{\circ} 000^{\prime} 46.8^{\prime \prime} \mathrm{S} \\
47^{\circ} 05^{\prime} 57.2 ” \mathrm{~W}\end{array}$} & \multirow{3}{*}{$19 / 05 / 2005$} & $\mathrm{CDC}$ & 304 \\
\hline & & & Aspirator & 361 \\
\hline & & & Shannon & 1759 \\
\hline \multirow{2}{*}{3} & $24^{\circ} 00^{\prime} 03.8^{\prime \prime} \mathrm{S}$ & \multirow{2}{*}{$02 / 06 / 2005$} & $\mathrm{CDC}$ & 143 \\
\hline & $47^{\circ} 06^{\prime} 09.0^{\prime \prime} \mathrm{W}$ & & Aspirator & 1 \\
\hline 4 & $\begin{array}{l}24^{\circ} 01 ' 31.7^{\prime \prime} \mathrm{S} \\
47^{\circ} 05^{\prime} 44.5^{\prime \prime} \mathrm{W}\end{array}$ & $08 / 12 / 2005$ & $\mathrm{CDC}$ & 5925 \\
\hline 5 & $\begin{array}{l}24^{\circ} 01^{\prime} 46.6^{\prime \prime} \mathrm{S} \\
47^{\circ} 05^{\prime} 40.4^{\prime \prime} \mathrm{W}\end{array}$ & 02/06/2005 & $\mathrm{CDC}$ & 996 \\
\hline \multirow{2}{*}{6} & $24^{\circ} 01^{\prime} 20.8 ” \mathrm{~S}$ & \multirow{2}{*}{--} & CDC & 57 \\
\hline & $47^{\circ} 05^{\prime} 18.4^{\prime \prime} \mathrm{W}$ & & Shannon & 3374 \\
\hline 7 & $\begin{array}{l}24^{\circ} 01^{\prime} 10.1^{\prime \prime} \mathrm{S} \\
47^{\circ} 05^{\prime} 08.4^{\prime \prime} \mathrm{W}\end{array}$ & -- & Shannon & 349 \\
\hline \multirow{2}{*}{8} & $23^{\circ} 59^{\prime} 28.7^{\prime \prime} \mathrm{S}$ & \multirow{2}{*}{-- } & Aspirator & 9 \\
\hline & $47^{\circ} 05^{\prime} 33.7^{\prime \prime} \mathrm{W}$ & & Shannon & 111 \\
\hline Total & & & & 13441 \\
\hline
\end{tabular}

\# Global Positioning System. *Date (DD/MM/YY) of the last malaria case detected by thick blood smear before the beginning of the entomological survey.

To verify the abundance of An. cruzii in a high forest cover in a steeper area in the proximity of the dwelling samples were collected at site 4 using $\mathrm{CO}_{2}$-baited UV-CDC traps. Most mosquitoes were captured in the wet season (January-March), as shown in Table 2. The comparison made in the varying altitudinal positions of CDCs showed statistical support $(\mathrm{Fr}=45.3, p<0.0001)$, meaning that there was a statistically 


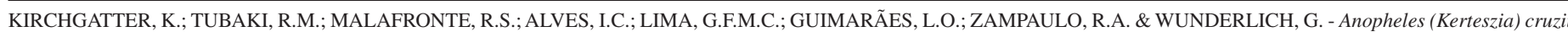
(Diptera: Culicidae) in peridomiciliary area during asymptomatic malaria transmission in the Atlantic Forest: molecular identification of blood-meal sources indicates humans as primary intermediate hosts. Rev. Inst. Med. Trop. Sao Paulo, 56(5): 403-9, 2014.

significant difference between the number of females collected according to the season.

Table 2

Seasonal activity of An. cruzii (William's mean) collected with $\mathrm{CO}_{2}$ baited UVCDC, at different altitudes at site 4, Juquitiba, during summer (Jan-Mar) and winter (Jul-Sep), 2006-2007, São Paulo

\begin{tabular}{cccccccc}
\hline $\begin{array}{c}\text { Position } \\
(\mathrm{m})\end{array}$ & $\begin{array}{c}\text { Altitude } \\
(\mathrm{m})\end{array}$ & Jan & Feb & Mar & Jul & Aug & Set \\
\hline 10 & 711 & 2.1 & 1.0 & 1.6 & 0.1 & 0.0 & 0.3 \\
20 & 722 & 3.1 & 0.6 & 1.5 & 0.2 & 0.1 & 0.6 \\
30 & 729 & 2.6 & 0.9 & 0.6 & 0.3 & 0.1 & 0.2 \\
40 & 742 & 3.7 & 1.9 & 0.9 & 0.0 & 0.1 & 0.4 \\
50 & 740 & 4.3 & 1.0 & 2.5 & 0.5 & 0.2 & 0.5 \\
60 & 741 & 4.6 & 1.2 & 3.4 & 0.2 & 0.2 & 0.6 \\
70 & 755 & 4.3 & 2.1 & 2.0 & 0.4 & 0.2 & 1.2 \\
80 & 773 & 2.0 & 1.6 & 2.4 & 0.0 & 0.1 & 0.4 \\
90 & 779 & 4.1 & 2.1 & 2.1 & 0.2 & 0.1 & 0.8 \\
100 & 799 & 2.3 & 0.7 & 1.6 & 0.3 & 0.0 & 0.0 \\
\hline
\end{tabular}

The efficacy of CDC and Shannon traps as collection methods was compared by standardizing the number of collections and collectors, and also evaluated in the sites, where collections were conducted simultaneously (sites 1,2 and 6). The Williams mean of An. (Ker.) cruzii collected with Shannon traps suggested higher values than those obtained by CDC-CO $\mathrm{CO}_{2}$ traps (Fig. 2). The Wilcoxon test ( $\mathrm{W}=20.0, p=$ $0.19)$ showed no significant differences in the numbers of captured $A n$. (Ker.) cruzii collected by the two methods in the peridomiciliary sites.

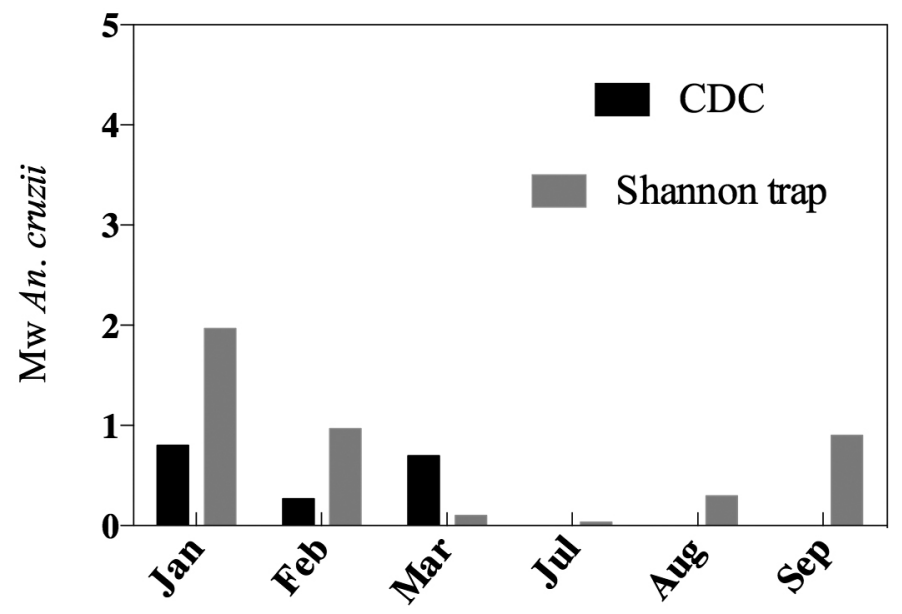

Fig. 2 - Comparison of collections with CDC and Shannon traps in the peridomiciliary sites 1, 2 and 6, in Juquitiba, São Paulo. The values were shown as William's mean of An. (Ker.) cruzii collected in the wet (Jan-Mar) and dry (Jul-Sep) seasons in 2006 and 2007.

Infection rate: Considering the large number of $A n$. (Ker.) cruzii females obtained, only $67.5 \%$ of the total $(9,072$ mosquitoes from 13,441 females) was tested for Plasmodium infection (1,119 and 7,953, collected in 2006 and 2007, respectively). From mosquitoes collected in 2006 , two pools, both from January $16^{\text {th }}$, were positive for $P$. vivax: one with females sampled from site 4 and another one with females obtained from site 5 . From those collected in 2007, one pool from site 4 , also from January $16^{\text {th }}$, was positive for $P$. vivax, and one pool sampled from site 6 on January $17^{\text {th }}$, was positive for P. malariae. All samples were collected with CDCs. The minimum infection rate (MIR) was $0.03 \%$ and $0.01 \%$ for $P$. vivax and P. malariae, respectively.

Blood meal identification: All engorged mosquitoes collected by CDC and Nasci aspirator (10 and 16 mosquitoes, respectively), in both years, were tested for blood meal identification (Table 3). Bloodmeal sources were successfully identified by DNA sequencing of the cytb fragment in $73 \%$ of engorged mosquitoes analyzed. In a total of $27 \%$ of engorged mosquitoes, no DNA from blood was detected, since the amplification of $c y t b$ gene was not obtained. All detected blood meals were identified as human-derived. In a more detailed analysis carried out using the PCR fragment sequence obtained from a mosquito (collected at site 2 in 2006 using Nasci aspirator), 730 bp were submitted to BLASTN to GenBank and only two substitutions were found in relation to a $c y t b$ sequence from Homo sapiens haplotype I [GenBank:EU091245].

Table 3

Number of blood-fed mosquitoes analyzed for blood meal identification, according to site, method and year of collection

\begin{tabular}{|c|c|c|c|c|c|}
\hline \multirow{3}{*}{$\begin{array}{l}\text { Collection } \\
\text { site }\end{array}$} & \multicolumn{5}{|c|}{ Blood meal source } \\
\hline & \multirow{2}{*}{ Method } & \multicolumn{2}{|c|}{2006} & \multirow{2}{*}{$\begin{array}{c}2007 \\
\text { Human }\end{array}$} & \multirow{2}{*}{ Total } \\
\hline & & Human & ND & & \\
\hline \multirow{2}{*}{2} & $\mathrm{CDC}$ & - & - & 01 & 01 \\
\hline & Aspirator & 02 & - & 03 & 05 \\
\hline \multirow{2}{*}{3} & $\mathrm{CDC}$ & - & - & - & - \\
\hline & Aspirator & 01 & - & - & 01 \\
\hline 4 & $\mathrm{CDC}$ & - & 05 & 02 & 07 \\
\hline 5 & $\mathrm{CDC}$ & - & - & 01 & 01 \\
\hline 6 & CDC & - & - & 01 & 01 \\
\hline 8 & Aspirator & 08 & 02 & - & 10 \\
\hline Total & & 11 & 07 & 08 & 26 \\
\hline
\end{tabular}

$\mathrm{ND}=$ not determined

\section{DISCUSSION}

This study reports molecular identification of blood-meal sources, seasonal abundance and malaria infectivity in Anopheles (Kerteszia) cruzii (Diptera: Culicidae) from a small focus of malaria transmission in a non-endemic area in the Atlantic Forest, São Paulo, Brazil. To the authors' knowledge, this is the first report using a molecular methodology based on cytochrome $b$ sequences to identify the blood-meal source carried out with mosquitoes collected during malaria transmission in Brazil.

During the sampling period, a good amount of mosquitoes were obtained, with the vast majority $(97.2 \%)$ collected by CDC and Shannon traps. Although an excessive number of Kerteszia females were collected 


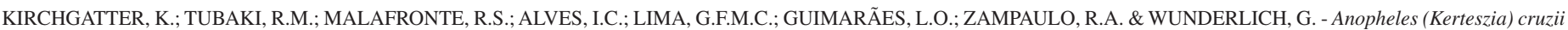

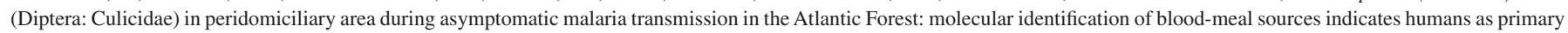
intermediate hosts. Rev. Inst. Med. Trop. Sao Paulo, 56(5): 403-9, 2014.

at the three sites in the wet season of 2007 with the Shannon trap, the Wilcoxon test results showed no significant difference between CDC and Shannon traps. CDC collection frequencies compensated negative collections with Shannon traps in the dry season. Negative collections must have occurred due to unidentified specific environmental conditions.

Human malaria cases in the Atlantic Rain Forest, as well as infected mosquitoes, were described by several authors $\mathrm{s}^{3,4,12,31}$, and the finding of natural infections of $P$. vivax and $P$. malariae in anophelines from this study match those detected by these authors. Also, the herein used molecular identification method is able to identify one naturally infected mosquito in a pool of ten mosquitoes and has been used in many other studies $^{3,12}$. Here, the minimum infection rate (MIR) was $0.03 \%$ and $0.01 \%$ for $P$. vivax and $P$. malariae, respectively. Similar rates were found by using ELISA methodology in anophelines collected in the same city ${ }^{1}$ or by using PCR-based techniques, in Parelheiros, a locality at a distance of $70 \mathrm{~km}$ from Juquitiba and also located in Atlantic Forest regions ${ }^{12}$. Altogether, these rates are well around ten times lower than in endemic regions in the Amazon ${ }^{19}$. It is important to note that the positive mosquitoes were collected with CDCs on January $16^{\text {th }}, 2006$, at sites 4 and 5 , and on February $17^{\text {th }}$, 2006, one additional malaria case was detected at site 5. In 2007, the positive mosquitoes were also collected in January, at sites 4 and 6. Perhaps not coincidentally, in February and March, five malaria cases were detected in the region by thick blood smear. The complete data of the epidemiological investigation will be published elsewhere.

Studies of feeding preferences of An. cruzii in the state of São Paulo using precipitin tests showed the presence of equine blood and rodent blood, but mainly human blood among the engorged mosquitoes ${ }^{14,15}$. However, the methods used in these studies did not allow the differentiation of human blood and simian blood. Here, a molecular approach capable of discriminating, at the species level, the source of the blood meal was used. Notably, mosquitoes were collected during the transmission season, in an area where malaria can be considered a zoonosis. Notwithstanding, only human blood was identified in the mosquitoes. Importantly, although the blood meal source was not identified for some of the mosquitoes examined, this result was also found in previous studies, using another ${ }^{14}$ or the same methodology ${ }^{2}$. This probably occurs due to the fact that the blood begins to be digested soon after ingestion by the mosquito and, as a consequence, the DNA is being degraded. Consequently, the longer the post-ingestion period, the lower the possibility of DNA detection ${ }^{29}$. Ultimately, it is important to note that the methodology used here for blood meal identification is one of the most widely used all over the world and is able to reliably detect blood from all vertebrates with the same performance ${ }^{22}$.

In relation to the collection method used to obtain engorged females, very few mosquitoes were captured with the Nasci aspirator, although this was properly used. Females of the Kerteszia subgenus are deliberately exophilic, resting in natural outdoor shelters, but it was assumed that the mosquitoes were rare or flew away with the proximity of the collectors. On the other hand, using CDC traps, other studies also showed a lower probability of collecting engorged mosquitoes, since they collect females that are actively host-seeking ${ }^{33}$. Thus, the analysis of the results showed that the methods for collecting mosquitoes employed here are reliable tools to sample Kerteszia females and showed regularity in accordance with seasonal periods of Kerteszia activity. However, it would be desirable to improve and standardize the collection methods to enable comparisons of results of different studies.

The participation of An. cruzii as a vector of Plasmodium in Atlantic Forest regions is recognized in Brazil, as well as the strong dependence of this species on the forest ${ }^{17}$. The predominance of this vector in the peridomiciliary area was confirmed, as well as the capacity of transmitting $P$. malariae and $P$. vivax. However, only human blood was recorded in the engorged mosquitoes. Given the significant sampling reached herein, the complete absence of detection of monkey blood does not favor the hypothesis of considering malaria cases as a zoonosis, and the occurrence of asymptomatic infections can possibly explain the maintenance of the circulation of parasites in humans, in the peridomiciliary habitat. Complementary studies testing the infection rates of monkeys in the study area may elucidate what real risk these animals play in terms of apparently very rarely occurring interspecies transmission of malaria.

\section{CONCLUSION}

In the present study, the predominance of An. (Ker.) cruzii was confirmed in the peridomiciliary area, as well as the capacity of transmitting $P$. malariae and $P$. vivax and the first molecular study of identification of the blood-meal source carried out with mosquitoes collected during asymptomatic malaria transmission in the Brazilian Atlantic Forest was reported. As only human blood was identified in the engorged mosquitoes, this data reinforce the hypothesis that asymptomatic human carriers are the main source of anopheline infection in the peridomiciliary area.

\section{RESUMO}

\section{Anopheles (Kerteszia) cruzii (Diptera: Culicidae) em área peridomiciliar durante transmissão de malária assintomática na Mata Atlântica: identificação molecular das fontes de repasto sanguíneo indica humanos como hospedeiros intermediários primários}

Anopheles (Kerteszia) cruzii é o vetor primário das malárias humana e simiana fora da Amazônia Brasileira e especificamente nas regiões de Mata Atlântica. A presença de casos humanos assintomáticos, macacos silvestres positivos para Plasmodium e a similaridade entre os parasitas que os infectam suportam a discussão se essas infecções podem ser consideradas como zoonoses. Embora muitos aspectos da biologia de An. cruzii já tenham sido abordados, estudos conduzidos durante surtos de transmissão de malária, visando a análise de repasto sanguíneo e infectividade, são ausentes na Mata Atlântica. Este estudo foi conduzido na localidade de Palestina, Juquitiba, Mata Atlântica do Estado de São Paulo, onde anualmente a maioria dos casos humanos autóctones é notificada. Locais em peridomicílio foram selecionados para coleta de mosquitos em um perímetro de até $100 \mathrm{~m}$ em torno das residências de casos humanos de malária e da floresta circundante. Os mosquitos foram analisados com o objetivo de identificação molecular das fontes de repasto sanguíneo e para examinar a prevalência de Plasmodium. Um total de 13.441 fêmeas de $A n$. (Ker.) cruzii foi coletado. A taxa de infecção mínima foi calculada a $0,03 \%$ e $0,01 \%$, respectivamente, para $P$. vivax e $P$. malariae e somente sangue humano foi detectado nos mosquitos analisados que se alimentaram com sangue. Nossos dados reforçam a hipótese de que 


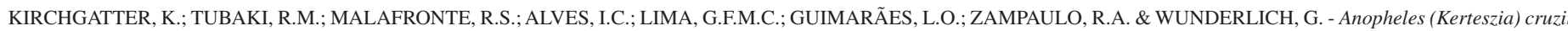
(Diptera: Culicidae) in peridomiciliary area during asymptomatic malaria transmission in the Atlantic Forest: molecular identification of blood-meal sources indicates humans as primary intermediate hosts. Rev. Inst. Med. Trop. Sao Paulo, 56(5): 403-9, 2014.

os portadores humanos assintomáticos são a principal fonte de infecção para os anofelinos na área do peridomicílio, tornando a transmissão zoonótica improvável.

\section{ACKNOWLEDGEMENTS}

This research was funded by FAPESP (03/06420-0).

\section{REFERENCES}

1. Branquinho MS, Marrelli MT, Curado I, Natal D, Barata JM, Tubaki R, et al. Infecção do Anopheles (Kerteszia) cruzii por Plasmodium vivax e Plasmodium vivax variante VK247 nos municípios de São Vicente e Juquitiba, São Paulo. Rev Panam Salud Publica. 1997;2:189-93.

2. Bueno MG, Lopez RPG, Menezes RMT, Costa-Nascimento MJ, Lima GFMC, Araújo RAS, et al. Identification of Plasmodium relictum causing mortality in penguins (Spheniscus magellanicus) from São Paulo Zoo, Brazil. Vet Parasitol. 2010;173:123-

3. Cerutti C Jr, Boulos M, Coutinho AF, Hatab MC, Falqueto A, Rezende HR, et al. Epidemiologic aspects of the malaria transmission cycle in an area of very low incidence in Brazil. Malar J. 2007;6:33.

4. Curado I, Malafronte RS, Duarte AMC, Kirchgatter K, Branquinho MS, Galati EAB. Malaria epidemiology in low-endemicity areas of the Atlantic Forest in the Vale do Ribeira, São Paulo, Brazil. Acta Trop. 2006;100:54-62.

5. CVE (Centro de Vigilância Epidemiológica). Situação epidemiológica da malária no Estado de São Paulo, 2007. Bol Epidemiol Paul. 2008;5(56):24-5. Available from: ftp://ftp.cve.saude.sp.gov.br/doc_tec/outros/bol_bepa5608.pdf

6. Deane LM, Deane MP, Ferreira Neto J. Studies on transmission of simian malaria and on a natural infection of man with Plasmodium simium in Brazil. Bull World Health Organ. 1966;35:805-8.

7. Deane LM, Ferreira Neto JA, Deane SP, Silveira IP. Anopheles (Kerteszia) cruzii, a natural vector of the monkey malaria parasites, Plasmodium simium and Plasmodium brasilianum. Trans R Soc Trop Med Hyg. 1970;64:647.

8. Deane LM, Ferreira-Neto JA, Lima MM. The vertical dispersion of Anopheles (Kerteszia) cruzii in a forest in southern Brazil suggests that human cases of malaria of simian origin might be expected. Mem Inst Oswaldo Cruz. 1984;79:461-3.

9. Deane LM. Simian malaria in Brazil. Mem Inst Oswaldo Cruz. 1992;87(Suppl 3):1-20.

10. Deane LM. Studies on simian malaria in Brazil. Bull World Health Organ. 1964;31:752-

11. Duarte AM, Malafronte RS, Cerutti C Jr, Curado I, de Paiva BR, Maeda AY, et al. Natural Plasmodium infections in Brazilian wild monkeys: reservoirs for human infections? Acta Trop. 2008;107:179-85.

12. Duarte AM, Pereira DM, de Paula MB, Fernandes A, Urbinatti PR, Ribeiro AF, et al. Natural infection in anopheline species and its implications for autochthonous malaria in the Atlantic Forest in Brazil. Parasit Vectors. 2013;6:58.

13. Escalante AA, Barrio E, Ayala FJ. Evolutionary origin of human and primate malarias: evidence from the circumsporozoite protein gene. Mol Biol Evol. 1995;12:616-26.

14. Forattini OP, Gomes AC, Natal D, Kakitani I, Marucci D. Preferências alimentares de mosquitos Culicidae no Vale do Ribeira, São Paulo, Brasil. Rev Saude Publica. 1987;21:171-87.

15. Forattini OP, Gomes AC, Natal D, Kakitani I, Marucci D. Preferências alimentares e domiciliação de mosquito Culicidae no Vale do Ribeira, São Paulo, Brasil, com especial referência a Aedes scapularis e Culex (Melanoconion). Rev Saude Publica. 1989;23:9-19.
16. Forattini OP, Kakitani I, dos Santos RC, Kobayashi KM, Ueno HM, Fernández Z. Potencial sinantrópico de mosquitos Kerteszia e Culex (Diptera:Culicidae) no Sudeste do Brasil. Rev Saude Publica. 2000;34:565-9.

17. Forattini OP, Kakitani I, Massad E, Marucci D. Studies on mosquitoes (Diptera:Culicidae) and anthropic environment. 11- Biting activity and blood-seeking parity of Anopheles (Kerteszia) cruzii in South-Eastern Brazil. Rev Saude Publica. 1996;30:107-14.

18. Forattini OP. Culicidologia médica. Identificação, biologia, epidemiologia. São Paulo: Edusp; 2002.v. 2.

19. Gil LH, Tada MS, Katsuragawa TH, Ribolla PE, da Silva LH. Urban and suburban malaria in Rondônia (Brazilian Western Amazon). II. Perennial transmissions with high anopheline densities are associated with human environmental changes. Mem Inst Oswaldo Cruz. 2007;102:271-6

20. Guimarães AE, Gentile C, Lopes CM, Mello RP. Ecology of mosquitoes (Diptera: Culicidae) in areas of Serra do Mar State Park, State of São Paulo, Brazil. II. Habitat distribution. Mem Inst Oswaldo Cruz. 2000;95:17-28.

21. Haddow AJ. Studies on the biting habits and medical importance of East African mosquitoes in the genus Aedes. I- Subgenera Aedimorphus, Banksinella and Dunnius. Bull Entomol Res. 1960;50:759-79.

22. Kent RJ. Molecular methods for arthropod bloodmeal identification and applications to ecological and vector-borne disease studies. Mol Ecol Resour. 2009;9:4-18.

23. Kocher TD, Thomas WK, MeyerA, Edwards SV, Pääbo S, Villablanca FX, et al. Dynamics of mitochondrial DNA evolution in animals: amplification and sequencing with conserved primers. Proc Natl Acad Sci USA. 1989;86:6196-200.

24. Köppen W. Climatologia: con un estudio de los climas de la tierra. México: Fondo de Cultura Economica; 1948.

25. Lim CS, Tazi L, Ayala FJ. Plasmodium vivax: recent world expansion and genetic identity to Plasmodium simium. Proc Natl Acad Sci USA. 2005;102:15523-8.

26. Marrelli MT, Malafronte RS, Sallum MA, Natal D. Kerteszia subgenus of Anophele associated with the Brazilian Atlantic rainforest: current knowledge and future challenges. Malar J. 2007;6:127.

27. Nasci RS. A lightweight battery-powered aspirator for collecting resting mosquitoes in the field. Mosq News. 1981;41:808-11.

28. Oliveira-Ferreira J, Lacerda MV, Brasil P, Ladislau JL, Tauil PL, Daniel-Ribeiro CT. Malaria in Brazil: an overview. Malar J. 2010;9:115

29. Oshaghi MA, Chavshin AR, Vatandoost H, Yaaghoobi F, Mohtarami F, Noorjah N. Effects of post-ingestion and physical conditions on PCR amplification of host blood meal DNA in mosquitoes. Exp Parasitol. 2006;112:232-6.

30. Pereira SL, Baker AJ. Vicariant speciation of curassows (Aves, Cracidae): a hypothesis based on mitochondrial DNA phylogeny. Auk. 2004;121:682-94.

31. Rezende HR, Soares RM, Cerutti C Jr, Alves IC, Natal D, Urbinatti PR, et al Entomological characterization and natural infection of anophelines in an area of the Atlantic Forest with autochthonous malaria cases in mountainous region of Espírito Santo State, Brazil. Neotrop Entomol. 2009;38:272-80.

32. SEADE (Fundação Sistema Estadual de Análise de Dados). Perfil Municipal de Juquitiba. 2012. [cited 2012 Oct 04]. Available from: http://www.seade.gov.br/produtos/perfil/ perfil.php

33. Service MW. Mosquito ecology field sampling methods. $2^{\text {nd }}$ ed. Essex: Elsevier Science Publishers; 1993.

34. Shannon RC. Methods for collecting and feeding mosquitoes in jungle yellow fever studies. Am J Trop Med Hyg. 1939;(s1-19):131-40. 


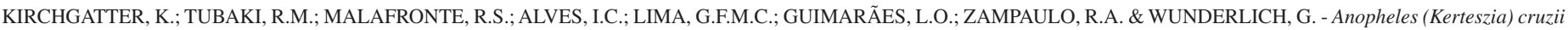
(Diptera: Culicidae) in peridomiciliary area during asymptomatic malaria transmission in the Atlantic Forest: molecular identification of blood-meal sources indicates humans as primary intermediate hosts. Rev. Inst. Med. Trop. Sao Paulo, 56(5): 403-9, 2014.

35. Sudia WD, Chamberlain RW. Battery-operated light trap, an improved model. Mosq News. 1962;22:126-9.

36. Ueno HM, Forattini OP, Kakitani I. Distribuição vertical e sazonal de Anopheles (Kerteszia) em Ilha Comprida, SP, Brasil. Rev Saude Publica. 2007;41:269-75.

37. Walter SD, Hildreth SW, Beaty BJ. Estimation of infection rates in populations of organisms using pools of variable size. Am J Epidemiol. 1980;112:124-8.

38. Win TT, Lin K, Mizuno S, Zhou M, Liu Q, Ferreira MU, et al. Wide distribution of Plasmodium ovale in Myanmar. Trop Med Int Health. 2002;7:231-9.
39. Yamasaki T, Duarte AM, Curado I, Summa ME, Neves DV, Wunderlich G, et al. Detection of etiological agents of malaria in howler monkeys from Atlantic Forests, rescued in regions of São Paulo city, Brazil. J Med Primatol. 2011;40:392-400.

40. Zavortink TJ. Mosquito studies (Diptera, Culicidae). XXIX. A review of the subgenus Kerteszia of Anopheles. Contrib Am Entomol Inst. 1973;9:1-54

Received: 17 January 2014

Accepted: 17 April 2014 